\title{
Çok Yüksek Hacimde Uçucu Kül İçeren Sentetik ve 5D Çelik Lif Donatılı Çimento Esaslı Kompozitlerin Mühendislik Özellikleri
}

\author{
Engineering Properties of Very High Volume Fly-ash Cementitious Composites \\ Reinforced with Synthetic and 5D Steel Fibers
}

\author{
Oğuzhan Öztürk ${ }^{1}$ iD \\ ${ }^{1}$ Konya Teknik Üniversitesi, İnşaat Mühendisliği Bölümü, 42250, Konya, Türkiye
}

Başvuru/Received: 23/09/2021Ｋabul/Accepted: 19/11/2021Ｃ̧evrimiçi Basım/Published Online: 31/01/2022

Son Versiyon/Final Version: 31/01/2022

\section{Öz}

Çimento esaslı kompozitlerde yüksek hacimlerde kullanılan uçucu küller ekonomik bir tasarımın yanında çeşitli taze ve sertleşmiş özellikleri modifiye etmektedir. Kullanılacak uçucu kül tipine göre değişmekle birlikte, istenen mühendislik özelliklerine göre seçilecek bir karışım tasarımı yüksek oranda uçucu külün kullanımını mümkün kılarak, çimento esaslı kompozitlerin içerisinde matris ile lif arasındaki ilişkiyi değiştirebilir. Bu çalışmada, toplam bağlayıcı ağırlığınca çok yüksek oranda (\%80) uçucu kül içeren çimento esasli kompozitler polyamid lif (PL) ve beş boyutlu çelik liflerle (5D-ÇL) tekli ve hibrit formda geliştirilerek mühendislik özellikleri açısından araştırılmıştır. Bunun yanında, lif donatılı kompozitlerin basınç mukavemetleri 7, 28, 60 ve 90 günlük kür yaşlarında belirlenmiştir. Tekli ve hibrit formda farklı tür lif donatılı çimento esaslı kompozitlerin mühendislik özellikleri, ilk çatlak gerilmesi ve kırılma noktalarındaki yük ve sehim değerleri, maksimum taşıma kapasitesi, süneklik oranı, rijitlik ve enerji yutma kapasitesi parametreleri dikkate alınarak değerlendirilmiştir. Sonuçlar bir arada kullanılan PL ve 5D-ÇL liflerinin tek formda kullanılmalarına göre matris-lif bağ davranışı açısından sinerji meydana getirdiğini ve buna bağlı olarak süneklik, başlangıç rijitlik ve enerji yutma kapasitelerini arttırdığını işaret etmektedir. Ayrıca tekil olarak lifler irdelendiğinde, 5D-ÇL'lerin PL liflerine göre mühendislik özelliklerini iyileştirmede daha etkili olduğu düşünülmektedir. Uçucu kül/çimento oranı ağırlıkça 4,0 olan kompozitlerin, erken yaş mekanik özelliklerin belirleyici olmadığı inşaat mühendisliği uygulamalarında ekonomiklik ve yapısal performans açısından sürdürülebilir bir tasarım olduğu düşünülmektedir.

\section{Anahtar Kelimeler}

"Uçucu kül, sentetik lifler, beș boyutlu çelik lifler, çimento esaslı kompozitler, mühendislik özellikleri"

\begin{abstract}
In cement-based mortars, using high volume of fly ash modifies several fresh and hardened properties besides an economical design. Although it varies according to the type of fly ash to be used, mixture design proving high amount of fly ash which is pre-targeted according to engineering properties may modify the relationship between matrix and fibers in the cement-based mortars. In this study, cement-based composites containing a very high percentage of fly ash $(80 \%)$ by total binder weight were developed with polyamide fiber (PL) and five-dimensional steel fibers (5D-ÇL) in single and hybrid forms and investigated in terms of engineering properties. In addition, compressive strength of fiber reinforced composites were assessed at the curing ages of 7, 28, 60 and 90 days. The engineering properties of cementitious composites reinforced with single and binary use of different fibers were obtained by considering load and displacement values at yield and fracture points, maximum load-carrying capacities, ductility, rigidity and energy dissipation capacity. Results reveal that binary use of PL and 5D-ÇL provided a synergy in terms of matrix-fiber bond behavior compared to their single use thus increasing the ductility, initial rigidity and energy dissipation capacities. In addition, in the case of examining single use of fibers, it was found that 5D-ÇL was more effective than PL fibers for improving the engineering properties. It is considered that composites having fly ash/cement ratio of 4.0 by weight are sustainable in terms of economically and performance in the civil engineering applications where early-age mechanical properties is not significative.
\end{abstract}

Key Words

"Fly ash, synthetic fibers, five dimensional steel fibers, cementitious composites, engineering properties" 


\section{Giriş}

Farklı tipteki çeşitli lif türleri bu zamana kadar çimento esaslı kompozitlerin çekme bölgesindeki davranışı iyileştirmek için araştırılmıştır (Nawy, 2001; Balaguru \& Shah, 1992). Harç veya beton gibi çimento esaslı kompozitlerde lif donatısı, karışımın taze halinden başlamak üzere meydana gelen çekme gerilmelerine karşı koymak amacıyla kullanılmaktadır. Farklı nedenlerle meydana gelen gerilmelerini aşmak için gerekli olan enerji ancak lif matris arasındaki bağ dayanımını aşmakla mümkün olmaktadır (Johnston, 2001). Endüstriyel olarak lif donatılı çimento esaslı malzemelerin kullanım alanları incelendiğinde; kaldırım, püskürtme beton, park alanları, apron, yükleme rampaları, dolu savak, prekast elemanların kullanıldığı tünel inşaatları, zirai yapılar, kanalizasyon elemanları, yol bariyer elemanları, döşemeler, temel ve drenaj elamanları gibi pek çok alan görülmektedir (Kumbhar vd. 2014). Son yıllarda, lif donatılı çimento esaslı kompozitler (LDÇK [fiber-reinforced cementitious composites]) alanında ortaya konulan çalışmalar dayanım ve dayanıklılık açısından yüksek performansa sahip sünek çimento esaslı malzemelerin geliştirdiğini göstermektedir (Li, 2003). Tercih edilen lif tipleri sadece mekanik özellikleri değil aynı zamanda karışımların boyutsal kararılığını da (örn. büzülme) modifiye etmektedir (Al-Kamyani vd. 2018). Konu ile ilgili başat çalışmalar liflerin meydana getirdiği performansın karışımlar içerisinde en çok dağılımı, türü ve narinlik oranı ile ilgili olduğunu göstermektedir (Mobasber vd. 1990; Betterman vd. 1995; Lawler vd. 2003). Kullanılan lif tipleri ise metalik liflerden; çelik, galvanize demir, alüminyum, mineral liflerden; cam, sentetik liflerden polyester, naylon, polietilen, doğal liflerden; ise bambu, ahşap, selüloz liflerin kullanıldığı görülmektedir (Dehghani \& Aslani 2020; Liu, 2018; Öztürk \& RoigFlores, 2021a; Öztürk \& Stefanidou, 2021b). Her ne kadar farklı tür mikro veya makro boyutlardaki lif donatıları çatlak tutma davranışı gösterse de, meydana gelen davranış kullanılan tek tip lifin bireysel özellikleri ile doğrudan ilişkilidir. LDÇK'ler alanında güncel son çalışmalar tek bir lif türünün hacim, narinlik ve diğer karakteristik özelliklerinin etkisinin daha az belirleyici olması için hibrit lif donatılı çimento esaslı kompozitleri (HLDÇK) ele almaktadır (Yoo \& Banthia, 2019; Zhang vd. 2021). Hibrit lif donatılandırılması, en az iki adet farklı tür ve özellikteki liflerin karışımların mühendislik özellikleri üzerinde aynı liflerin toplamda aynı hacimde tek tipte meydana getirebileceği ortalama performansı aşmayı amaçlamaktadır. Uygun bir hibrit lif donatısı sonucu ortaya çıkan bu olgunun adı liflerin "sinerjisi" olarak tanımlanmaktadır (Li vd. 2019; Wei vd. 2021). İlave maliyet ve karışım geliştirme zahmeti gerektirmeyen bu tasarımda birtakım yaklaşımlarda bulunmak zaruridir. Bunlar ilk olarak bir lifin daha rijit seçilerek makul bir ilk çatlak ve nihai dayanım sağlanması, diğer lifin ise görece daha sünek ve post-kırılma bölgesinde şekil değiştirme sağlayabilmesidir. İkinci olarak ise bir lif türünün belirgin olarak daha düşük boyutlarda tercih edilerek mikro çatlakları köprülemesidir. Buna bağlı olarak farklı çatlakların birleşmesinin geciktirilmesi daha büyük boyutlu diğer lifin makro çatlakları bir arada tutarak kırılma tokluğunu iyileştirmesi de beklenebilir. Son olarak, bir lif türü taze ve erken yaş özelliklerini düzenlerken (üretilme kolaylığı ve plastik büzülme), diğer lif türü ileri mekanik özelliklerin düzenlenmesi ile ilgili kriterlere göre seçilebilir.

Hibrit lif kullanımının yanında, iyileştirmek istenen mühendislik özellikleri (ilk çatlak gerilmesi ve kırılma noktalarındaki yük ve deplasman değerleri, maksimum taşıma kapasitesi, süneklik, rijitlik ve enerji yutma kapasitesi) tercih edilen diğer karışım kompozisyonları ile de yakından ilişkilidir. Örneğin yüksek hacimlerde kullanılan çeşitli mineral katkılar tamamen Portland çimentosu (PÇ) içeren sistemlere göre lif-matris arasındaki bağ dayanımını daha yüksek şekil değiştirme kapasitesi sağlayacak şekilde iyileştirmektedir. $\mathrm{Bu}$ durum özellikle yüksek hacimlerde kullanılması durumunda F-sınıfı uçucu küller (düşük $\mathrm{CaO}$ içeren) içeren karışımlarda rapor edilmiştir (Wang \& Li 2007). Karışım bünyesinde hidrate olmamış halde bulunan uçucu küller, lif donatılı karışımlarda lif-matris arasındaki kimyasal bağ dayanımını düşürmekte ve matris tokluğunu aşağıya çekmektedir. Öte yandan uçucu küller azalan kimyasal bağ dayanımına karşılık lif-matris arasındaki sürtünme kuvvetini arttırarak daha yüksek bir çekme şekil değiştirmesi elde edilmesine yardımcı olmaktadır. Ancak, F sınıfı uçucu küller çok daha yüksek oranlarda kullanıldığında (toplam bağlayıcı ağırlığınca 50\%'den fazla) düşük $\mathrm{CaO}$ içeriği ile puzolanik kapasitesi $\mathrm{C}$ sınıfı uçucu küllere göre daha yavaş olmakta ve erken yaş dayanım problemleri ile karşılaşılmaktadır. Ancak bu noktada mineral katkı tipinin yanında incelik derecesinin de çok etkili olduğu belirtilmelidir. Özellikle toplam bağlayıcı miktarınca \%80'e kadar F-sınıfı uçucu kül kullanıldığı karışımlarda yeterli basınç dayanımını (>25 MPa [TBDY, 2019]) sağlamak 28 günün çok ötesinde uzun kür süreleri (180 güne varan) gerektirmektedir (Hannesson vd. 2012). F sınıfı uçucu külün lif donatılı çimento esaslı sistemlerde avantaj sağladığı lif ile matris arası artan içsel sürtünme davranışını koruyarak yeterli mekanik özellikleri optimize etmek daha fazla hacimde uçucu kül kullanımını mümkün kılabilir. Bu durum daha ekonomik ve çevresel etkileri düşük bir karışım tasarımı sağlarken aynı zamanda yüksek şekil değiştirme kapasitesi korunabilir. C-sınıfı uçucu küller daha yüksek $\mathrm{CaO}$ içeriğine sahip olması nedeniyle aynı oranda $\mathrm{F}$ sınıfı uçucu kül kullanımına göre lif donatılı sistemlerde daha düşük sünekliğe neden olacağı beklenebilir. Ancak, C-sınıfı uçucu küllerin çok daha fazla hacimde kullanılması, F sınıfı uçucu küllerdeki puzolan olarak yer alan içeriklerin de $\left(\mathrm{SiO}_{2}+\mathrm{Al}_{2} \mathrm{O}_{3}+\mathrm{Fe}_{2} \mathrm{O}_{3}\right)$ aynı anda daha fazla yer almasına neden olacağından benzer bir lif-matris ilişkisi için uçucu kül kullanım oranı çok daha üst hacimlere çıkarılabilir (Liu vd. 2018).

Bu çalışmanın amacı, ekonomik ve çevre dostu bir tasarımın yanında, süneklik ve şekil değiştirme kapasitesini iyileştirmek için bütün karışımlarda tercih edilen sabit bir yüksek hacimdeki uçucu kül varlığında, hibrit lif donatılandırılması ile sürdürülebilir, ekonomik ve ileri mühendislik özelliklerine sahip yeni nesil çimento esaslı kompozitler geliştirmektedir. Bu amaçla, çok yüksek hacimde uçucu kül kullanılarak (uçucu kül/çimento oranı ağırlıkça 4.0 [toplam bağlayıcı ağırlığınca \%80]) bütün karışımlarda düşük yoğunlukta tekli ve hibrit lif donatısı ile çimento esaslı kompozitlerin mühendislik özellikleri açısından kritik performansları (ilk çatlak gerilmesi ve kırılma noktalarındaki yük ve deplasman değerleri, maksimum taşıma kapasitesi, süneklik, rijitlik ve enerji yutma kapasitesi) ele alınmıştır. Araştırmada, lif türü olarak polyamid (PL) ve beş boyutlu çelik lif (5D-ÇL) donatıları kullanılmıştır. Bütün karışımların yüksek oranda uçucu kül içermesi nedeniyle erken ve nihai yaştaki mekanik özellikleri bu tip kompozitlerin kullanılabilirliği açısından belirleyici olmaktadır. Bu nedenle bütün karışımların 7, 28, 60 ve 90 günlük yaşlardaki basınç dayanımları da ayrıca dikkate alınmıştır. 


\section{Materyal ve Metot}

\subsection{Malzemeler}

Karışımlarda EN 197-1 standardına göre uyumlu sıradan Portland çimentosu (PÇ) CEM I 42.5R kullanılmıştır. C-sınıfı uçucu küller (C-UK) toplam bağlayıcı ağırlı̆̆ının \%80'i oranında kullanılmış olup PÇ ve C-UK'ya ait fiziksel ve kimyasal özellikler Tablo 1'de verilmiştir. Karışımlarda maksimum tane boyut dağılımı $500 \mu \mathrm{m}$ olan silis kumu kullanılmıştır. Araştırmada ince agrega tane boyutu karışımlarda daha sünek performans elde edilmesi amacıyla sınırlandırılmıştır. Bilindiği üzere lifler arası boşluk mesafesi agrega ortalama tane boyutundan büyük olduğu durumlarda liflerin matris içerisinde topaklanma derecesi artmaktadır. Bu nedenle homojen dağılmama riski olan liflerin sünek bir tasarım için gereken çatlak köprüleme performansları azalmaktadır. Kullanılan silis kumuna ait elek analiz dağılımı Tablo 2'de verilmiştir.

Tablo 1. Portland çimentosu (PÇ), C sınıfı uçucu külün (C-UK) ve silis kumunun özellikleri

\begin{tabular}{lccc}
\hline Kimyasal içerik, \% & PÇ & C-UK & Silis kumu \\
\hline $\mathrm{SiO}_{2}$ & 20.8 & 35.5 & 98.86 \\
$\mathrm{Al}_{2} \mathrm{O}_{3}$ & 5.45 & 12.95 & 0.24 \\
$\mathrm{Fe}_{2} \mathrm{O}_{3}$ & 3.25 & 11.78 & 0.15 \\
$\mathrm{MgO}$ & 2.42 & 2.33 & 0.10 \\
$\mathrm{CaO}$ & 61.6 & 17.76 & 0.01 \\
$\mathrm{Na}$ & 0.19 & 0.15 & 0.02 \\
$\mathrm{~K}_{2} \mathrm{O}$ & 0.77 & 1.44 & 0.03 \\
$\mathrm{~K}_{21 \text { dirma kayb }}$ & 2.20 & 2.84 & 0.07 \\
$\mathrm{SiO}_{2}+\mathrm{Al}_{2} \mathrm{O}_{3}+\mathrm{Fe}_{2} \mathrm{O}_{3}$ & 29.7 & 60.23 & 99.25 \\
$\mathrm{Fiziksel} \mathrm{özellikler}$ & & & \\
Özgül ağırlı & 3.06 & 2.40 & 2.60 \\
\hline
\end{tabular}

Tablo 2. Silis kumunun tane dağılımı

\begin{tabular}{cccccc}
\hline Elek çapı & $500-710^{\mu \mathrm{m}}$ & $355-500^{\mu \mathrm{m}}$ & $250-355^{\mu \mathrm{m}}$ & $180-250^{\mu \mathrm{m}}$ & $0-180^{\mu \mathrm{m}}$ \\
Geçen (\%) & 0.08 & 0.28 & 2.53 & 31.08 & 99.67 \\
\hline
\end{tabular}

Karışımlar yoğun olarak ince taneli kuru malzemeler (PÇ+C-UK+ince silis kumu) ve farklı lifler içermektedir. Bu nedenle, her karışım tipi için yeterli bir akıcı yayılma sağlamak ve taze karışımların yayılma özelliklerini modifiye etmek amacıyla polikarboksilik-eter esaslı yüksek oranda su azaltıcı katkı kullanılmıştır. Polyamid lif (PL) ve beş boyutlu çelik liflerin (5D-ÇL) özgül ağırlıkları sırasıyla 1,14 ve 7,80'dir. PL'lerin uzunlukları $12 \mathrm{~mm}, 550 \mu \mathrm{m}$ çapında ve nominal çekme dayanımı $900 \mathrm{MPa}$ 'dır. İki ucu kancalı 5D-ÇL ise 39 narinlik oranına sahip olup nominal çekme dayanımı 2300 MPa'dır. Karışımlarda kullanılan PL ve 5D-ÇL liflerin görüntüsü Şekil 1'de verilmiş olup liflere ait özellikler Tablo 3 'te sunulmuş̧ur.

Tablo 3. PL ve 5D-ÇL’lerin özellikleri

\begin{tabular}{lcc}
\hline Özellikler & PL & 5D-ÇL \\
\hline Narinlik oranı & 308 & 39 \\
Çap & $550(\mu \mathrm{m})$ & $0.9(\mathrm{~mm})$ \\
Nominal çekme dayanımı & $900 \mathrm{MPa}$ & $2300 \mathrm{MPa}$ \\
Özgül ağırlık & 1.14 & 7.80 \\
\hline & & \\
\hline
\end{tabular}

Şekil 1. Tekil ve hibrit lif donatılı çimento esaslı kompozitlerde kullanılan farklı tür ve özellikte PL (solda) ve 5D-ÇL’ler (sağda) 


\subsection{Karışım Oranları ve Üretimi}

Hibrit lif donatılı çimento esaslı kompozit (HLDÇK) karışımlarına ait içerikler Tablo 4'te verilmiştir. Deneylerde daha önce bahsedildiği üzere hibrit lif donatılı kirişler üretmek amacıyla PL ve 5D-ÇL birlikte kullanılmıştır. Aynı zamanda karşılaştırma yapmak amacıyla tekil olarak PL ve 5D-ÇL'in yer aldığı karışımlar da üretilmiştir (Tablo 4). Yüksek oranda kullanılan C-sınıfı uçucu kül miktarı (toplam bağlayıcı ağırlığının \%80'i) çalışmanın ana amacı olan kompozitlerin hibrit ve tekil lif etkisindeki davranışını belirlemek için sabit tutulmuştur. Karışımlarda kum/toplam bağlayıcı (Kum/TB) oranı 0,46'dır. Aynı şekilde bütün karışımlarda su (S) /toplam bağlayıcı miktarı (PÇ+C-UK) oranı (S/TB) 0,37 olarak sabit tutulmuştur. Toplam uçucu kül ağırlığı/Portland çimentosu oranı (C-UK/PÇ) ise 4,0'dır.

Karışımların üretimi sırasında, ilk olarak Portland çimentosu (PÇ), C sınıfı uçucu kül (C-UK) ve kum ile kuru karışım iki dakika boyunca dakikada 60 çevrim olacak şekilde $(60 \mathrm{rpm})$ çimento harç mikserinde yapılmıştır. Ardından karışım suyu ve toplam kullanılan yüksek oranda su azaltıcı katkının (YOSAK) yarısı ilave edilmiş ve üç dakika boyunca aynı şekilde 60 rpm'de karışım sürdürülmüştür. Ardından PL ve/veya 5D-ÇL devam eden karışımlara eklenmiştir. Liflerin karışımlara eklenmesinin ardından YOSAK'ın diğer yarısı ilave edilmiş ve karışım 120 rpm'de ilave beş dakika boyunca devam ettirilmiştir. Küp ve kiriş kalıplar için toplamda 80,1 litre olmak üzere üç farklı karışımda üretim yapılmıştır. Hazırlanan taze karışımlar ardından $360 \times 75 \times 50 \mathrm{~mm}$ (uzunluk $\times$ yükseklik $\times$ genişlik) kiriş ve bir boyutu $100 \mathrm{~mm}$ olan küp kalıplara dökülmüştür. Kalıplara alınan taze karışımların üstü plastik örtülerle kapatılmış ve laboratuvar şartlarında ortam kürü $50 \pm 5 \%$ bağıl nem ve $25 \pm 2^{\circ} \mathrm{C}$ 'de beş gün süresince uygulanmıştır. Üretilen harçların kalıplarda beş gün boyunca bekletilme nedeni bütün karışımların yüksek hacimde uçucu kül içermesi (\%80) nedeniyle kalıp alma süresinin genel yaklaşımlara kıyasla (1-2 gün) daha uzun olmasıdır. Kalıplardan alınan numuneler ardından test edileceği farklı kür yaşlarına kadar suda kür edilmiştir.

Tablo 4. Yüksek oranda uçucu kül içeren tekil ve hibrit lif donatılı çimento esaslı kompozitlerin karışım miktarı ve oranları

\begin{tabular}{|c|c|c|c|c|c|c|c|c|c|c|}
\hline Karışım Adı & $\mathbf{P C}{ }^{1}$ & C-UK ${ }^{1}$ & Kum $^{1}$ & $\mathrm{Su}^{1}$ & 5D-ÇL ${ }^{1}$ & $\mathbf{P L}^{1}$ & YOSAK $^{1}$ & Kum/TB ${ }^{2}$ & $\mathrm{C}-\mathrm{UK} / \mathrm{PC}{ }^{2}$ & $\mathrm{~S} / \mathrm{TB}^{2}$ \\
\hline PL/DÇK & 218 & 866 & 500 & 400 & - & 13 & 40 & 0,46 & 4,0 & 0,37 \\
\hline HBL/DÇK & 218 & 866 & 500 & 400 & 36 & 6,5 & 40 & 0,46 & 4,0 & 0,37 \\
\hline 5DÇL/DÇK & 218 & 866 & 500 & 400 & 72 & - & 40 & 0,46 & 4,0 & 0,37 \\
\hline
\end{tabular}

\subsection{Deneysel Program}

Üç farklı karışıma ait küp numunelerin basınç dayanımları 7, 28, 60 ve 90 günlük kür yaşlarında belirlenmiştir. Her bir karışımdan altı adet numune ilgili kür yaşlarında basınç deney presi altında $1,0 \mathrm{kN} / \mathrm{s}$. hızda test edilmiştir. 28 günlük $360 \times 75 \times 50 \mathrm{~mm}$ (uzunluk $\times$ yükseklik $\times$ genişlik) boyutlarındaki kiriş numuneler ise her karışımdan ikişer adet olmak üzere dört noktalı eğilme deneyi altında test edilmiştir. Yükleme hızı $0.05 \mathrm{kN} / \mathrm{s}$. hızda yapılmıştır. Dört noktalı eğilme deneyinde kiriş numuneler alt mesnetlere numune kenarlarından $25 \mathrm{~mm}$ mesafede olup üst mesnetler ise orta açıklık eşit aralıklı üç parçada (L/3=100,3 mm) olacak şekilde düzenlenmiştir (Şekil 2). Yük verileri (N) maksimum 30 ton kapasiteli yük hücresi tarafindan $0,001 \mathrm{~N}$ hassasiyetinde kaydedilirken orta açılık sehimi $(\mathrm{mm})$ ise doğrusal değişken diferansiyel transformatör (LVDT) aracılığıyla 0,0001 mm hassasiyetinde kaydedilmiştir. Bu verilerden yararlanılarak kiriş numunelerin yük-orta açıklık sehim grafikleri elde edilmiş ve yüksek hacimde uçucu kül içeren farklı tür liflerle donatılandırılmış kiriş numunelerin mühendislik özellikleri irdelenmiştir. Geliştirilen lif donatılı çimento esaslı kompozitlerin mühendislik özelliklerine dair parametreler ilk çatlak gerilmesi ve kırılma anındaki yük ve sehim performansları, süneklik oranı, rijitlik ve enerji yutma kapasitesi olarak belirlenmiştir. Kiriş numunelerin ilk çatlak gerilmesi noktaları (yük [N] ve sehim [mm]), yük-orta açıklık sehim eğrisinde ilk çatlağın meydana geldiği ve eğrinin doğrusallığının bozulduğu nokta olarak belirlenmiş̧ir. Rijitlik değerleri ise ilk çatlak gerilme bölgesine kadar meydana gelen ve elastik olduğu varsayılan yük-orta açıklık sehim eğrisi dikkate alınarak belirlenmiştir $(\mathrm{N} / \mathrm{mm})$. Bu aşamadan sonra meydana gelen sehime karşıllık yük taşıma kapasitesinin azalması ve ardından kirişlerin tekrar artan yük altında sehim yapmaya devam etmesi (şekil değiştirme sertleşmesi) sırasında süneklik ve maksimum enerji yutma kapasiteleri belirlenmiştir. Kiriş numunelerin ilk çatlak gerilme noktasından sonra şekil değiştirme sertleşmesi gösterdiği maksimum yükün \%85'ine karşılık gelen nokta kırılma noktası olarak belirlenmiştir (Öztürk, 2021). Süneklik oranları her bir kiriş için kırılma noktasındaki sehim kapasitesinin $(\mathrm{mm})$ ilk çatlak gerilme noktasındaki sehim kapasitesine $(\mathrm{mm})$ oranı olarak dikkate alınmıştır. Enerji yutma kapasitesi ise yük başlangıcından kırılma noktası olarak belirlenen yere kadar dikkate alınan yük-orta açıklık sehim eğrisinin altında kalan alanın tamamı olarak hesap edilmiştir. Bu değerlendirmelerde ASTM C1609 (Lif donatılı betonların eğilme performansı için test yöntemi) dikkate alınmıştır. Söz konusu parametreler Şekil 3’te ayrıca sunulmuştur. 


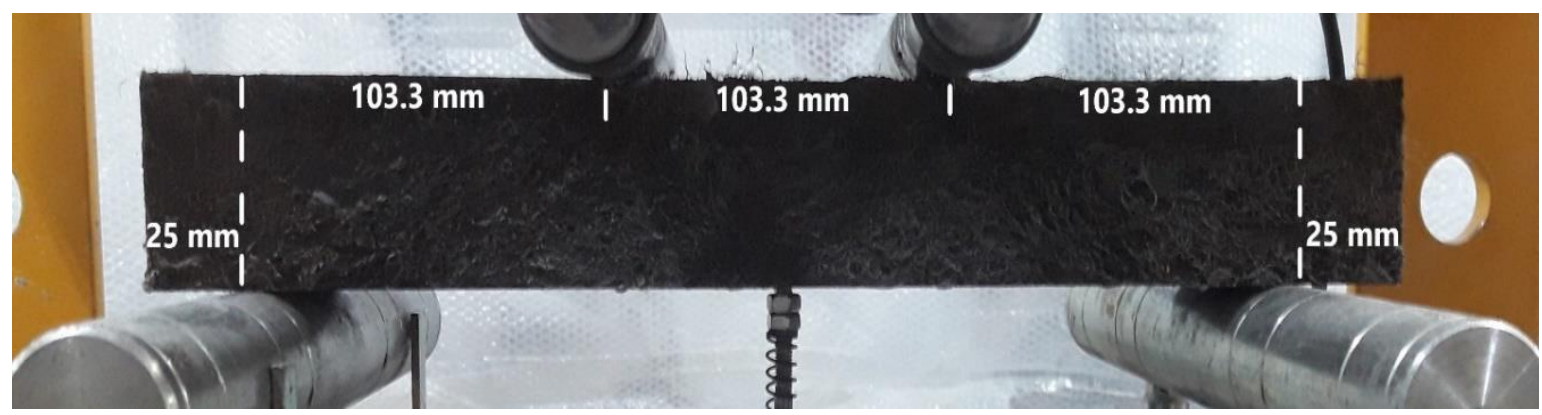

Şekil 2. Tekil ve hibrit lif donatılı çimento esaslı kompozitlerin dört noktalı eğilme deneyi

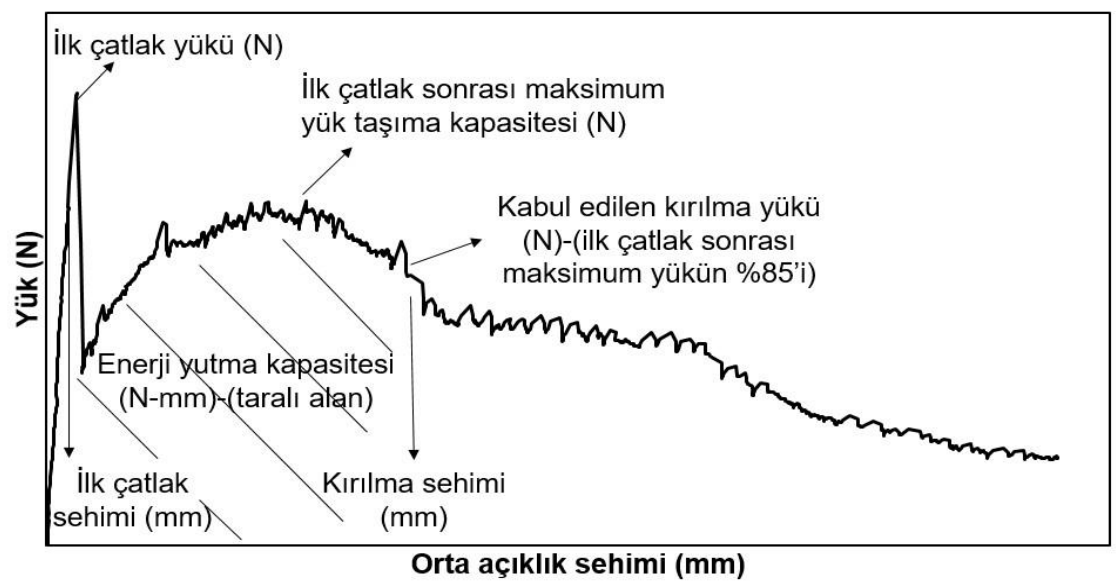

Şekil 3. Lif donatılı çimento esaslı kompozitlerin tipik yük (N) - orta açıklık sehim (mm) eğrisi ve hesap parametreleri

\section{Bulgular ve Tartışma}

\subsection{Karışımların Basınç Mukavemetleri}

Tekil ve hibrit halde liflerle donatılandırılmış ve yüksek hacimde uçucu kül içeren çimento esaslı kompozitlerin basınç mukavemetleri Şekil 4'te sunulmuştur. Şekil 4'te görüleceği üzere, PL/DÇK, HBL/DÇK ve 5DL/DÇK karışımlarına ait altışar numunenin ortalama basınç dayanımları 7. Gün sonunda sırasıyla 12,1, 11,8 ve 10,0 MPa olarak kaydedilmiştir. Aynı şekilde ilerleyen kür yaşlarında PL/DÇK karışımı için 28, 60 ve 90 günlük ortalama basınç dayanımları 22,3 35,1 ve 38,9 MPa elde edilmiştir. HBL/DÇK ve 5DL/DÇK karışımları için ise sırasıyla aynı kür yaşlarında 19,8, 33,5 38,6 MPa ve 18,1 30,7, 33,9 MPa olarak ortalama basınç mukavemet değerleri belirlenmiş̧ir. Elde edilen sonuçlarda, geleneksel hazır betonların 7 günlük kür yaşlarına kıyasla elde edilen basınç dayanım gelişimleri düşük olarak yorumlanabilir. Aynı şekilde bütün karışımların 28 günlük ortalama basınç mukavemetleri değerlendirildiğinde, PL/DÇK, HBL/DÇK ve 5DL/DÇK karışımları için elde edilen ortalama basınç mukavemetlerinin (sırasıyla 22,3, 19,8 18,1 MPa) Türkiye Bina Deprem Yönetmeliğinde (TBDY, 2019) beton küp numuneler için verilen 28 günlük basınç mukavemeti şartının (<30 MPa) altında olduğu görülmektedir (Şekil 4). Ancak ilerleyen kür yaşlarında (60 gün) tekil veya hibrit lif donatılı çok yüksek hacimde uçucu kül (C-UK/PÇ: 4,0) içeren harçların tamamının ortalama $30 \mathrm{MPa}$ 'dan daha yüksek bir basınç dayanımına sahip olduğu görülmektedir. Aynı şekilde 90 günlük numunelere bakıldığında PL/DÇK, HBL/DÇK ve 5DL/DÇK karışımlarının teorik olarak kabul edilen minimum yapısal beton basınç mukavemet değerinden (30 MPa, [TBDY, 2019]) sırasıyla \%29,6\%28,7 ve \%13 daha yüksek olduğu görülecektir (Şekil 4).

Elde edilen sonuçlarda özellikle erken yaş dayanımların geleneksel betonların 7 günlük yaşlardaki basınç mukavemetlerine kıyasla düşük olması beklenen bir durum olarak değerlendirilmektedir. Bu durumun nedeni karışımlarda yoğun bir şekilde kullanılan (\%80 oranında) uçucu küllerle ilişkilendirilebilir. Her ne kadar uçucu kül inceliği, morfolojisi ve hidrolik bağlayıcılık yeteneği $(\mathrm{CaO}$ içeriği) erken yaşlardaki hidratasyon kazanma hızına etki etse de, özellikle bağlayıcı olarak PÇ ile \%50'den daha fazla bir yer değiştirme oranında kullanıldığında genellikle uçucu küller en az 7 günden sonra hidratasyon derecesini arttırmaktadır (Moon vd. 2016). Bu durum bütün kür yaşları incelendiğinde özellikle 7 ile 28 gün arasında meydana gelen artış oranlarında daha belirgin olarak görülmektedir. Örneğin PL/DÇK, HBL/DÇK ve 5DL/DÇK karışımları için 28. Gündeki basınç dayanımı, 7 günlük basınç dayanımlarından sırasıyla $\% 84,3, \% 67,8$ ve $\% 81$ daha büyüktür. Her ne kadar 60 günlük numuneler 28 günlük numunelerle, 90 günlük numuneler ise 60 günlük numunelerle karşılaştırıldığında açıkça görülen bir artıştan söz edilse de basınç mukavemetinin yönelimindeki artış hızı azalarak devam etmiştir. Karışımların erken yaşlarda göstermiş oldukları düşük basınç dayanımı gelişimleri uçucu küllerin genel olarak puzolanik reaksiyon kapasitesinin yavaş olması ile ilgilidir. Bu durum özellikle her üç karışımında yüksek oranda uçucu kül içermesi durumunda 
çok daha belirgin hale gelmiştir. Bu çalışmanın ana amacı, tekil ve hibrit liflerin çimento esaslı kompozitlerdeki mühendislik özelliklerine etkisini irdelemek olduğundan, uçucu küller yüksek oranda ancak tek seviyede (C-UK/PÇ: 4,0) kullanılmıştır. Bu nedenle erken yaşlardaki basınç mukavemetlerinde uçucu kül muhtevası etkisi farklı dozajlarda sınanarak özellikle 28.gündeki basınç mukavemet değerleri istenen seviyelere ( $>30 \mathrm{MPa}$ ) çıkarılabilir. Bunun yanında \%80 uçucu kül muhtevası korunarak agrega tane paketlenme (Sunayana \& Barai 2017) tasarımı, mikronize kalsit (Demirel \& Demirhan, 2021) veya nano silis (Öztürk vd. 2020) gibi katkılarla yoluyla da hidratasyon derecesi hızlandırılabilir.

Uçucu küller ile ilgili olarak $\mathrm{CaO}$ içeriğinden bağımsız olarak yapılan genel kanılar, her ne kadar erken yaşta puzolanik olarak hidratasyon derecesini üzerinde az etkisi olsa da PÇ’ye göre genellikle daha ince taneli olmasından dolayı dolgu ve çekirdeklenme etkisi ile ilgilidir (Lawrence vd. 2003; Rahhal \& Talero 2005). Ancak bu çalışmada, her ne kadar çalışmanın ana amacı gereği karşılaştırmalı olarak farklı dozajlarda uçucu küller araştırılmasa da, söz konusu incelik etkisine bağlı erken yaşlarda (7.gün) olumlu bir hidratasyon derecesi artışının meydana gelmediği söylenebilir. Bu durumun temel nedeni Çoban Yıldızı Termik Santralinden (Konya) temin edilen C-sınıfı uçucu külün (\%17,76-CaO) incelik derecesinin çalışmada kullanılan Portland Çimentosundan dahi (325 $\mathrm{m}^{2} / \mathrm{kg}$ ) iri olması ile ilişkilendirilebilir. Öte yandan, Türkiye genelinde çeşitli F veya C sınıfı uçucu küllere bakıldığında, bu çalışmada kullanılan uçucu küllerin aksine, daha ince taneli uçucu kül tiplerinde de mevcut karışımlar ileriye dönük olarak tekrar sınanabilir. Örneğin, Orhaneli Termik Santralinden (Bursa) elde edilen F sınıfı, $\left(>400 \mathrm{~m}^{2} / \mathrm{kg}\right.$ ), Kangal Termik Santralinden (Sivas) elde edilen C sınıf ( $\left(>330 \mathrm{~m}^{2} / \mathrm{kg}\right.$ ) veya Tunçbilek Termik Santralinden (Kütahya) elde edilen F sınıfı uçucu küller $\left(>370 \mathrm{~m}^{2} / \mathrm{kg}\right)$ mevcut karışımlara dolgu ve çekirdeklenme etkisi açısından daha fazla avantaj sunabilir. Bununla birlikte $\% 80$ oranında uçucu kül muhtevasına sahip bir harç karışımının bu çalışmada test edilen en geç kür yaşı olan 90 günün de ötesinde basınç dayanımı gelişimi gösterebileceği düşünülmektedir. Örneğin Hannesson vd. (2012) araştırmasında toplam bağlayıcı hacminin \%80’i oranında C sınıfı uçucu küllerin kullanıldığı karışımlarda kontrol karışımlarına kıyasla (\%100 PÇ içeren) aynı basınç mukavemetinin elde edilmesinin 168 gün sürdüğünü rapor edilmiştir. Benzer şekilde inşaat mühendisliği alanındaki çeşitli altyapı uygulamalarının ihtiyaçlarına bağlı olarak kalıp alma süresi ve hizmete açılacağı gün gibi kriterler dikkate alınması şartıyla, yoğun uçucu kül kullanımının harç ve betonlarda daha önce bahsedildiği üzere mekanik, dürabilite ve ekonomik bir tasarım açısından uzun dönemde çok çeşitli avantajlar sunacağı düşünülmektedir. Öte yandan, mevcut çalışma yoğun uçucu kül içeren karışımların erken yaş dayanımını 7.Gündeki basınç mukavemet değerlerini dikkate alarak değerlendirmiştir. Ancak bilinmektedir ki, yavaş gelişen hidratasyon derecesi mekanik etkiden daha çok özellikle çok daha erken yaşlarda değişen çevresel koşullar altında daha kritik bir hal alabilir. Örneğin geleneksel betonun priz süresinin tamamlanması sırasında yaklaşık olarak 0.7 MPa basınç dayanımının belirtildiği durumlarda (Mehta, 2005), \%80 uçucu kül içeren sistemler için priz süresinin tamamlanmasının çok daha uzun olacağı açıktır. Bu nedenle bu tip karışımlar için uzun bakım ve kür gerektiren durumlarda, özellikle donma/çözünme olaylarının etkisindeki matriste suyun donması durumunda hidratasyonun bir daha devam etmemesi ya da düzensiz hidratasyon gelişimleri riski oluşabileceğinden daha dikkatli bir kür ve korumanın zaruri olduğu belirtilmelidir.

Şekil 4'te verilen sonuçlara göre, tekil ve hibrit lif içeren karışımların basınç dayanımına etkileri de ayrıca irdelenebilir. Örneğin, deney sonuçlarından elde edilen verilerin tamamında görüleceği üzere, her bir kür yaşında en yüksek basınç mukavemeti PL/DÇK karışımı ile elde edilmiş olup daha sonra bu karışımı sırasıyla HBL/DÇK ve 5DL/DÇK numuneleri takip etmiştir. Her ne kadar karışımların ortalama basınç mukavemet değerlerinde belirgin bir farklılık izlenmese de, genel olarak bütün kür yaşlarında makro tipte (5D-ÇL) çelik lifin kullanıldığı durumlarda, mikro tipteki (PL) liflere göre basınç mukavemetlerinde azalış meydana geldiğinden bahsedilebilir. Bu durum özellikle daha yüksek oranda 5D-ÇL'in kullanıldığı (\%1) 5DL/DÇK karışımı ile daha düşük 5D-ÇL'in kullanıldığı $(\% 0,5)$ HBL/DÇK karışımları arasında dahi izlenebilir (Şekil 4). Elde edilen bu sonuçlar makro liflerin üniform ve eksenel olarak etkiyen basınç yükleri altında meydana getirdiği daha yüksek oranda bozulan çelik lif-matris ara yüzü ile ilgili olabilir. Elde edilen bulgulara literatürde makro liflerin basınç dayanımına etkisi ile ilgili çalışmalarda da rastlanmaktadır (Şahmaran \& Yaman, 2007; Öztürk vd. 2021). Bunun yanında Zheng et al. (2018) çalışmalarında düşük-orta dayanımlı betonlardan ziyade yüksek dayanımlı betonlarda çelik liflerin daha olumlu etkisi olduğunu rapor etmişlerdir. Bu çalışmadaki karışımların ortalama basınç dayanımları 7 ve 28 günlük yaşlarda görece daha düşük (<30 MPa) dayanımda, 60 ve 90 günlük yaşlarda ise orta dayanımlı basınç mukavemeti sergilediğinden $(>30 \mathrm{MPa})$ farklı lif tip ve dozajındaki karışımlar ayrıca daha yüksek dayanımlı betonlarda irdelenebilir. Ancak basınç mukavemet değerleri karşılaştırılırken, TBDY 2019'da kıyas edilen dayanım değerlerinin 150 mm'lik küp numuneler için geçerli olduğu ve bu çalışmadaki basınç testlerinin bir boyutu $100 \mathrm{~mm}$ olan küp numunelerle yapıldı̆̆ı da dikkate alınmalıdır. 


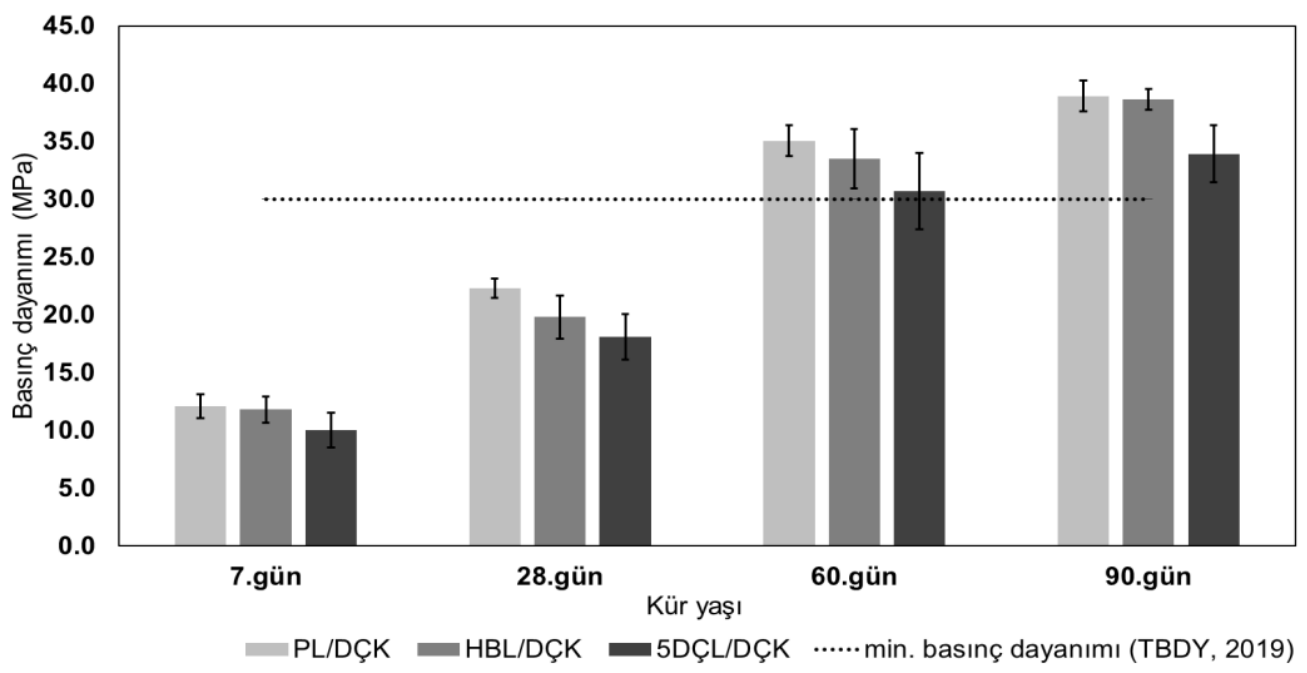

Şekil 4. Tekil ve hibrit lif donatılı yüksek hacimde uçucu kül içeren çimento esaslı kompozitlerin farklı kür sürelerindeki ortalama basınç mukavemetleri

\subsection{Tekil ve Hibrit Lif Donatılı Kirişlerin Mühendislik Özellikleri}

Farklı tür liflerle tekil ve hibrit olarak üretilen kiriş numunelerin 4 noktalı eğilme yükleri altında meydana gelen yük $(\mathrm{N})$ ve orta açıklık sehim $(\mathrm{mm})$ grafikleri Şekil 5.a-c'de verilmiştir. Her bir karışıma ait numunelerin yük $(\mathrm{N})$ ve orta açıklık $(\mathrm{mm})$ grafiklerinden belirlenen çeşitli mühendislik özellikleri ayrıca Tablo 5’te detaylı olarak sunulmuştur. Öncelikle kirişlerin yük-orta açıklık grafikleri genel olarak incelendiğinde, PL/DÇK kirişlerinin meydana gelen ilk çatlağın ardından eğilme yük taşıma kapasitesinde diğer karışımlara ait kirişlere kıyasla daha fazla düşüş meydana gelmiştir. İlk çatlağın meydana gelmesinin ardından, orta açıklık sehimine karşılık yük ekseninde her ne kadar pekleşme meydana gelmişse de bu durum diğer kiriş numunelerine kıyasla (Şekil 5.b-c) sınırlı olmuştur. Öte yandan, yük taşıma kapasitesi ise diğer kiriş numunelerinden daha uzun orta açıklık sehimi yaparak devam etmiş olup ortalama 4,68 mm deformasyon seviyesinde deney sona ermiştir (Tablo 5). Hibrit lif donatılı çimento esaslı kompozitler (HBL/DÇK) incelendiğinde ise ilk çatlak gerilme noktası olarak kabul edilen ilk çatlağın meydana gelmesinin ardından eğilme yük ekseninde düşüş PL/DÇK karışımlarına kıyasla sınırlı kalmış ve HBL/DÇK kiriş numunelerin her ikisi de çok belirgin şekilde ilk çatlak gerilmesi sonrasında pekleşme göstermiştir (Şekil 5.b). Meydana gelen daha yüksek pekleşme seviyesinin yanında, pekleşme süresi ve pekleşme sonrası davranış incelendiğinde PL/DÇK içeren karışımlara HBL/DÇK kirişleri yük taşıma kapasitelerini daha uzun süre devam ettirmiştir. Ortalama olarak HBL/DÇK kirişleri için orta açıklık sehim (mm) seviyesi 5,63 mm'ye geldiğinde ise (Tablo 5) deney cihazı durarak kirişlerin yük taşıma kapasitesi sona ermiş̧ir. Beş boyutlu çelik lif donatılı çimento esaslı kompozitlerin (5DÇL/DÇK) davranışına genel olarak bakıldığında ise (Şekil 5.c) kirişlerin ilk çatlak gerilmesi noktalarının eğilme yük seviyesi olarak daha yüksek noktalarda meydana geldiği görülecektir. İlk çatlak gerilmesi sonrası yük taşıma kapasitesindeki düşüş ise HBL/DÇK kirişlerine benzer şekilde daha sınırlı meydana gelmiştir. Ancak her iki 5DÇL/DÇK karışımına ait kirişlerin pekleşme performansları diğer iki tip karışıma göre (PL/DÇK ve HBL/DÇK) daha üst eğilme yük seviyesinde meydana gelmiştir. Öte yandan 5DÇL/DÇK kirişlerinin pekleşme aralığı, ilk çatlak gerilmesi sonrası maksimum taşıma seviyesi ve kırılmaya kadar devam eden orta açıklık sehim kapasiteleri dikkate alındığında ise tekil PL $(\% 1)$ ve hibrit olarak PL $(\% 0,5)$ ve 5DÇL $(\% 0,5)$ içeren kirişlere göre daha düşük bir sehim kapasitesi gösterdiği görülmektedir. Daha önce bahsedildiği üzere PL/DÇK ve HBL/DÇK kirişlerinin ortalama nihai sehim kapasitesi sırasıyla 4,68 ve 5,63 mm elde edilmesine karşın, 5DÇL/DÇK kirişlerinin ortalama nihai sehim kapasitesi 2,87 olarak kaydedilmiştir (Tablo 5).

Şekil 5'e genel olarak bakıldığında, PL/DÇK ve HBL/DÇK'e ait farklı kiriş numunelerin yük $(\mathrm{N})$ ve orta açılık sehim (mm) grafiklerinin kendi içerisinde birbirine daha benzer olduğu görülecektir. Ancak, 5DÇL/DÇK kirişlerine ait grafiklerdeki yük $(\mathrm{N})$ ve orta açıklık sehim (mm) ilişkisinin ise birbirinden daha fazla fark içerdiği görülecektir (Şekil 5.c). Bu durumun temel sebebi, makro boyuttaki 5DÇL etkisinin, mikro boyutta tek bir tipte lif içeren (PL/DÇK) ve daha az miktarda 5DÇL içeren (HBL/DÇK) karışımlara kıyasla meydana gelen farklılıklardan daha büyük olması ile ilişkilendirilebilir. 


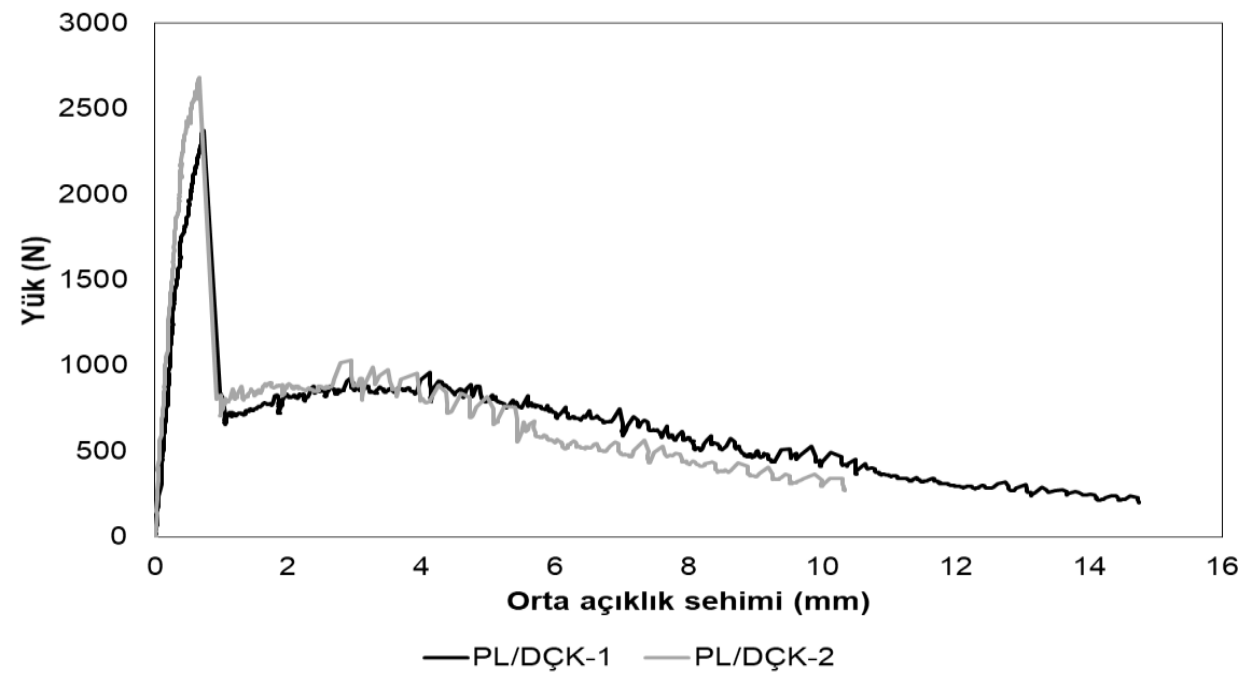

a) \%1 polyamid (PL) lif donatılı çimento esaslı kompozitler

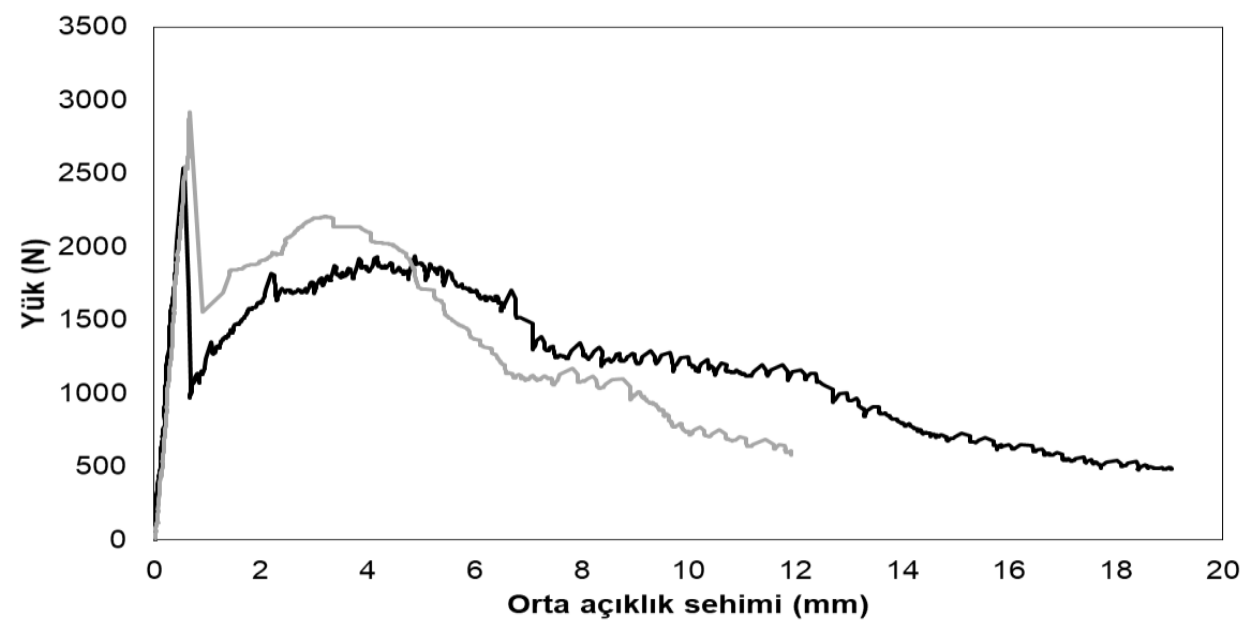

-HBL/DÇK-1 - HBL/DÇK-2

b) \%0,5 polyamid (PL) ve \%0,5 beş boyutlu çelik (5D-ÇL) lif donatılı çimento esaslı kompozitler

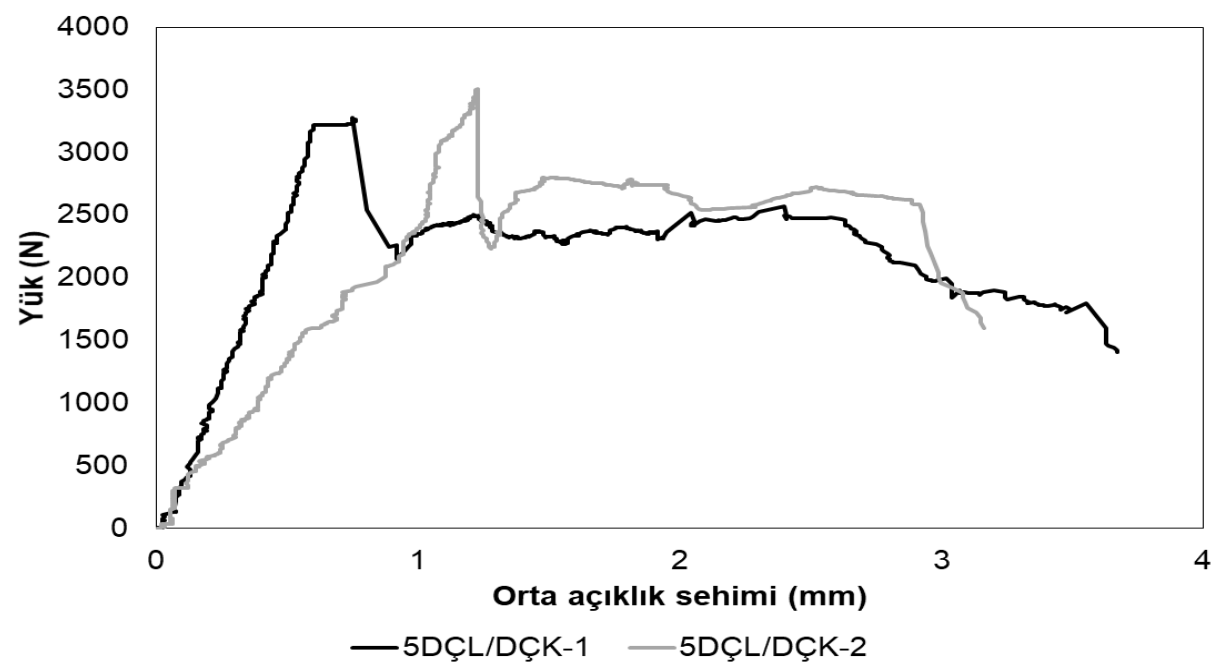

c) \%1 beş boyutlu çelik (5D-ÇL) lif donatılı çimento esaslı kompozitler

Şekil 5. Tekil ve hibrit lif donatılı çimento esaslı kompozitlerin yük $(\mathrm{N})$ - orta açıklık sehimi (mm) 
Tablo 5. Yüksek oranda uçucu kül içeren tekil ve hibrit lif donatılı çimento esaslı kompozitlerin mühendislik özellikleri İlk çatlak noktası

Kirılma

\begin{tabular}{|c|c|c|c|c|c|c|c|c|}
\hline \multirow[b]{2}{*}{ Kiriş adı } & & \multirow[b]{2}{*}{$\begin{array}{c}\text { İlk çatlak } \\
\text { sonrası } \\
\text { maks. yük } \\
\text { (N) }\end{array}$} & & \multirow[b]{2}{*}{$\begin{array}{c}\text { Süneklik } \\
\text { Oranı }\end{array}$} & \multirow[b]{2}{*}{$\begin{array}{c}\text { Başlangıç } \\
\text { rijitlik } \\
\text { (N/mm) }\end{array}$} & \multirow[b]{2}{*}{$\begin{array}{c}\text { Enerji yutma } \\
\text { kapasitesi } \\
\text { (N.mm) }\end{array}$} \\
\hline & $\begin{array}{l}\text { Yük } \\
(\mathbf{N})\end{array}$ & $\begin{array}{l}\text { Orta açıklık } \\
\text { sehimi } \\
(\mathbf{m m})\end{array}$ & & $\begin{array}{l}\text { Yük } \\
(\mathbf{N})\end{array}$ & $\begin{array}{l}\text { Orta açıklık } \\
\text { sehimi } \\
(\mathbf{m m})\end{array}$ & & & \\
\hline PL/DÇK-1 & 2372 & 0,73 & 962,2 & 813,7 & 5,10 & 6,98 & 3249,3 & 4842,7 \\
\hline PL/DÇK-2 & 2684 & 0,66 & 1035,4 & 886,9 & 4,26 & 6,45 & 4066,7 & 4521,5 \\
\hline Ortalama & 2528 & 0,70 & 998,8 & 850,3 & 4,68 & 6,72 & 3658,0 & 4682,1 \\
\hline HBL/DÇK-1 & 2546 & 0,58 & 1937,3 & 1646,0 & 6,44 & 11,14 & 4407,1 & 10662 \\
\hline HBL/DÇK-2 & 2923 & 0,66 & 2208,0 & 1876,8 & 4,82 & 7,30 & 4428,8 & 9167,2 \\
\hline Ortalama & 2734,5 & 0,62 & 2072,7 & 1761,4 & 5,63 & 9,22 & 4417,5 & 9914,6 \\
\hline 5DÇL/DÇK-1 & 3276,5 & 0,75 & 2568 & 2182,7 & 2,80 & 3,73 & 4368,6 & 6294,4 \\
\hline 5DÇL/DÇK-2 & 3503,5 & 1,23 & 2801,4 & 2380,8 & 2,94 & 2,39 & 2848,4 & 6490,2 \\
\hline Ortalama & 3390 & 0,99 & 2684,7 & 2281,8 & 2,87 & 3,06 & 3608,5 & 6392,3 \\
\hline
\end{tabular}

Bu çalışma, yüksek oranda uçucu kül ihtiva eden çimento esaslı kompozitlerde kullanılan tekil ve hibrit lif donatıların numunelerin ilk çatlak gerilme noktası (yük [N] ve orta açıklı sehimi [mm]), ilk çatlak gerilmesi sonrası maksimum yük seviyesi, kırılma noktası (yük $[\mathrm{N}]$ ve orta açıklık sehimi [mm]), süneklik oranı, başlangıç rijitlik $(\mathrm{N} / \mathrm{mm})$ ve enerji yutma kapasitelerine (N.mm) etkisini irdelemiş olup numunelere ait mühendislik özelliklerinin tespitinde daha önce verilen (Şekil 3) parametreler kullanılmışıtır. Farklı karışımların ilk çatlak gerilme noktasındaki yük seviyesi irdelendiğinde (Tablo 5), 5D çelik lif içeren karışımlara ait kirişlerin (5DÇL/DÇK) ortalama ilk çatlak gerilme yüklerinin en yüksek olduğu görülecektir (3390 N). Bu karışımı sırasıyla HBL/DÇK (2734,5 N) ve PL/DÇK $(2528 \mathrm{~N})$ takip etmiştir. Görüleceği üzere, sırasıyla daha yoğun $(\% 1)$, orta yoğunluklu $(\% 0,5)$ ve 5D çelik lifinin kullanılmadığı PL/DÇK karışımlarına doğru gidildikçe ilk çatlak gerilme yükünün meydana geldiği seviye düşmektedir. Bu durumun en temel sebebi 5D-ÇL etkisi olup bir sentetik lif olan PL'ye kıyasla daha az uzama seviyesine ve daha yüksek elastik modüle sahip olması ile ilişkilidir. Belirli bir çatlak genişliğine karşılık gelen yük için PL'ler daha az ilk çatlak gerilme yükü ile bu çatlağı karşılarken, çelik lif içeren numunelerde ilk çatlak gerilme yük seviyesi daha üst noktalarda meydana gelmiş olabilir. Her ne kadar bu duruma karşllık beklenen ilk çatlak gerilme noktasına karşılık gelen ilk çatlak gerilme sehminin $(\mathrm{mm})$ daha düşük olması beklense de HBL/DÇK için ilk çatlak gerilme seviyesi ortalama olarak 0,99 mm'de gerçekleşmiştir. PL/DÇK ve HBL/DÇK için ise daha benzer noktalarda ilk çatlak gerilme seviyelerinin oluştuğu söylenebilir (Tablo 5). Bu durum daha çok beş boyutlu çelik liflerin ilk çatlak gerilme yükünü çok daha fazla yükte karşılarken, farklı liflerin çalışma özelliklerinin tam olarak ayırt edilmeye başlaması ile ilgili olabilir. Örneğin, ilk çatlak noktasında meydana gelen PL'lerinin bazılarının muhtemel sıyrılmasının daha erken bir ilk çatlak gerilme sehimi meydana getirdiği düşünülmektedir. Benzer durum ilk çatlak gerilme noktasından sonra da görülebilir. İlk çatlak gerilme noktasından sonra meydana gelen maksimum yük seviyeleri incelendiğinde, davranış üzerinde giderek daha fazla oranda 5D-ÇL'lerin etkili olmaya başladığı görülecektir. Bu durum ilk çatlak gerilme sonrası en yüksek yük taşıma kapasitesinden görülebilir (Tablo 5). Örneğin, 5DÇL/DÇK, HBL/DÇK ve PL/DÇK kirişlerinin ortalama maksimum yükleri sırasıyla 2684,7, 2072,7 ve 998,8 N olarak kaydedilmiştir. Ancak ilk çatlak gerilmesinin ardından devam eden şekil değiştirme yumuşamasının başladığı bölge (ilk çatlak gerilme noktası sonrası maksimum yük seviyesinden bu yükün \%85'ine kadar devam eden bölge [Şekil 3]) dikkate alındığında, ilk çatlak gerilme noktası sonrası maksimum yük seviyesinde 5DÇL/DÇK kirişlerinin daha düşük sehim yaptığı görülecektir (Tablo 5). Bu durum ilk çatlak gerilmesi sonrasından kırılma bölgesine kadar çelik liflerin yüksek elastisite modülüne bağlı olarak en yüksek çekme gerilmesini (2684,7 N) daha düşük şekil değiştirme kapasitesi ile taşıdığını göstermektedir (Al-Kamyani vd. 2018).

HBL/DÇK kirişleri incelendiğinde ise çimento esaslı kompozitlerin hibrit lif donatısı ile gevrek davranıştan çok uzaklaştığı görülmektedir. Aynı şekilde, ilk çatlak gerilmesi sonrasından pekleşme bölgesine ve devamında maksimum yük seviyesinden bu yükün \%85'ine kadar devam eden bölge dikkate alındığında hibrit lif donatılı her iki kirişinde diğer karışımlara oranla daha yüksek orta açıklık sehimine $(\mathrm{mm})$ sahip olduğu görülecektir. Sayısal olarak ifade etmek gerekirse HBL/DÇK kirişleri, 5DÇL/DÇK ve PL/DÇK kirişlerinden kırılma noktasında ortalama olarak sırasıyla $\% 96,1$ ve $\% 20,3$ daha fazla sehim yapma performansı göstermiş̧ir. ilk çatlak gerilme noktasında HBL/DÇK kirişlerinin daha az miktarda ilk çatlak gerilme sehimine karşıllk, devam eden pekleşme ve pekleşme sonrası davranışında meydana gelen bu çok belirgin değişikliğin temel sebebi, farklı tür liflerin eğilme yükleri altında farklı görev yaparak bir sinerji meydana getirdiği ve buna bağlı olarak söz konusu mühendislik özelliklerini iyileştirmesidir. Hibrit lif kullanımında PL ve 5D-ÇL'lerin sinerjisi ise PL liflerinin erken yükleme döneminden itibaren çelik liflerle beraber matrise etkiyen gerilmeyi ve numunenin alt yüzeyinden üst kısmına kadar giderek genişleyen çatlak gelişimini ortak olarak paylaşmasıdır. Bu durum sırasında çatlak genişlikleri arttıkça PL lifleri sıyrılma veya daha ileri yüklerde liflerin bireysel olarak kopma sonucu çatlak genişlikleri sınırlı tutulmuştur. Bu esnada makro boyutta 5D-ÇL'ler devam eden eğilme yükleri altında başarılı bir şekilde yük taşıma kapasitesi için katkıda bulunurken artan yük altında daha fazla sehim yapma kapasitesi mümkün olmuştur. Giderek artan eğilme yükleri ile sehim derecesi artmış ve bu noktada makro boyuttaki 5D-ÇL lifler ilk çatlak gerilmesi sonrası maksimum yükten kırılmaya kadar giderek artan çatlak genişliklerinde rol oynamıştır. Bir başka deyişle, yüklemenin başından sonuna kadar HBL/DÇK kirişlerinin davranışı 
değerlendirildiğinde, nominal dayanımı $900 \mathrm{MPa}$ olan PL lifler ilk olarak daha düşük genişlikteki çatlak uçlarında eğilme yüklerine bağlı gerilemeyi azaltmıştır. Gerilme konsantrasyonlarının çatlak uçlarında PL aracılığıyla dağılmasının ardından, diğer karışımlara kıyasla daha dar çatlak genişliğinde daha fazla yükü 5D-ÇL'ler karşılamıştır. Böylece, yüklemenin giderek artması ile lokalize olan çatlak gelişimlerini 5D-ÇL'ler daha fazla enerjinin gerektiği kırılma yükleri altında taşıma kapasitesine sahip olmuştur. Benzer bulgular literatürdeki bazı çalışmalarla da örtüşmektedir (Wei vd. 2021). Öte yandan bu gelişimin yaşanmadığı tekil olarak 5D çelik liflerin yer aldığı karışımlarda (5DÇL/DÇK) sözü edilen davranış gözlemlenmemiştir (Şekil 5).

Tekil olarak PL liflerinin yer aldığı PL/DÇK karışımlarına ait kirişler incelendiğinde 5DÇL/DÇK kirişlerine kıyasla daha yüksek ortalama kırılma sehim kapasitesi (4,68 mm [Tablo 5]) elde edilse de, ilk çatlak gerilmesi noktasından başlamak üzere, ilk çatlak sonrası maksimum yük taşıma kapasitelerinde önemli düşüşler mevcuttur. Bu durum mikro çatlakların genişlemesini engelleyen PL liflerinin artan eğilme yükleri neticesinde daha geniş çatlakları köprüleme yeteneğinin ortadan kalktı̆̆ını göstermektedir. Bu noktada daha rijit ve nominal çekme gerilmesi PL liflerine göre yaklaşı 2,5 kat daha fazla olan (2300 MPa) çelik liflerin karışımda yer almaması daha sünek ancak yük taşıma kapasitesi açısından en düşük karışımın PL/DÇK kirişlerine ait olmasına sebep olmuştur. Tablo 5'e bakıldığında, PL/DÇK kirişlerinin, ortalama ilk çatlak gerilme yükü (2528 N), ortalama ilk çatlak gerilmesi sonrası maksimum yük $(998,8 \mathrm{~N})$ ve ortalama kırılma yükü $(850,3)$ açısından en düşük yük kapasitesinin kaydedildiği karışım olduğu görülecektir.

Bireysel olarak karışımların analizlerinin yanında elde edilen değerlere göre Tablo 5'te sunulan süneklik oranı, başlangıç rijitlik $(\mathrm{N} / \mathrm{mm}$ ) ve enerji yutma kapasitesi, (N.mm) gibi özellikler üzerinden kirişlerin ortalama performansları sayısal olarak irdelenebilir. Daha önce bahsedildiği üzere daha yüksek yük seviyesinde daha fazla sehim yapma kapasitesi gösteren HBL/DÇK'ler, kırılma anındaki sehimin $(\mathrm{mm})$ ilk çatlak anındaki sehime $(\mathrm{mm})$ oranı olarak ifade edilen süneklik derecesinde 5DÇL/DÇK kirişlerinden yaklaşık 3 kat, $\mathrm{PL} / \mathrm{DÇK}$ kirişlerinden ise yaklaşık 1,4 kat daha fazla sünektir. Bunun yanında, her ne kadar süneklik oranı ve enerji yutma kapasiteleri kadar (N.mm) belirgin olmasa da, HBL/DÇK'lerin başlangıç rijitlikleri sırasıyla PL/DÇK ve 5DÇL/DÇK kirişlerinin ortalama değerlerinden yaklaşık \%20 ve \%22 daha fazladır. Daha önce detaylı olarak bahsedildiği üzere, hibrit lif kullanımında meydana gelen bu iyileşmeler ile kirişlerin yük $(\mathrm{N})$ - orta açıklık sehimi $(\mathrm{mm})$ eğrilerinin altında kalan alan olarak tanımlanan enerji yutma kapasitesi (N.mm) HBL/DÇK kirişleri için 9914,6 N.mm olarak elde edilmiştir (Tablo 5). Öte yandan enerji yutma kapasiteleri, 5DÇL/DÇK ve PL/DÇK kirişleri için sırasıyla 6392,3 N ve 4682,1 N olarak kaydedilmiştir. Tablo 5'in yanında, kirişlerin ilk çatlak gerilme davranış1 sonrası kaybettikleri yük taşıma kapasitesini geri kazanma oranını gösteren ilk çatlak gerilmesi sonrası maksimum yük (N)/ ilk çatlak gerilmesi yükü (N) oranı Şekil 6'da ayrı olarak sunulmuştur. Farklı türde tekil ve hibrit lif donatılı kirişlerin kırılma sonrasına ait görüntülerine bakıldığında genel olarak liflerin tamamının (PL ve 5D-ÇL) homojen dağıldığından söz edilebilir (Şekil 7). Örneğin Şekil 7.a'ya bakıldığında, gözle yapılan muayene sonucu \%1 oranında kullanılan PL liflerinin kiriş kesit yüzeylerinde flokülleşme meydana getirmediği görülebilir. Benzer olarak, Şekil 7.c'de verildiği üzere 5D çelik liflerin bulunduğu yönler açısından kesit genelindeki oryantasyona bakıldığında rastgele bir dizilimin başarıldığından söz edilebilir. Hibrit formda kullanılan PL ve 5D çelik liflerinin ise diğer iki karışıma kıyasla gözle yapılan muayene sonucu tek bir çatlak noktasından ayrılma yerine, ilk çatlağın başladığı noktadan çatlağın lokalize olduğu noktaya kadar çeşitli yan çatlaklar meydana getirdiği tespit edilmiştir. Bunun yanında, kırılma esnasında 5D çelik lifleri sahip olduğu çatlak ucu avantajı ile (5D) kirişleri parçalayarak sıyrılmıştır. Bu durum hibrit formdaki kirişlerin daha fazla yük altında daha fazla sehim yaptığını ve sonuç olarak Şekil 5-6 ve Tablo 5'te detaylı olarak aktarılan mühendislik özelliklerinin iyileştirildiğini doğrulamaktadır.

\section{Akma sonrası maksimum yük (N) / Akma yükü (N) oranı}

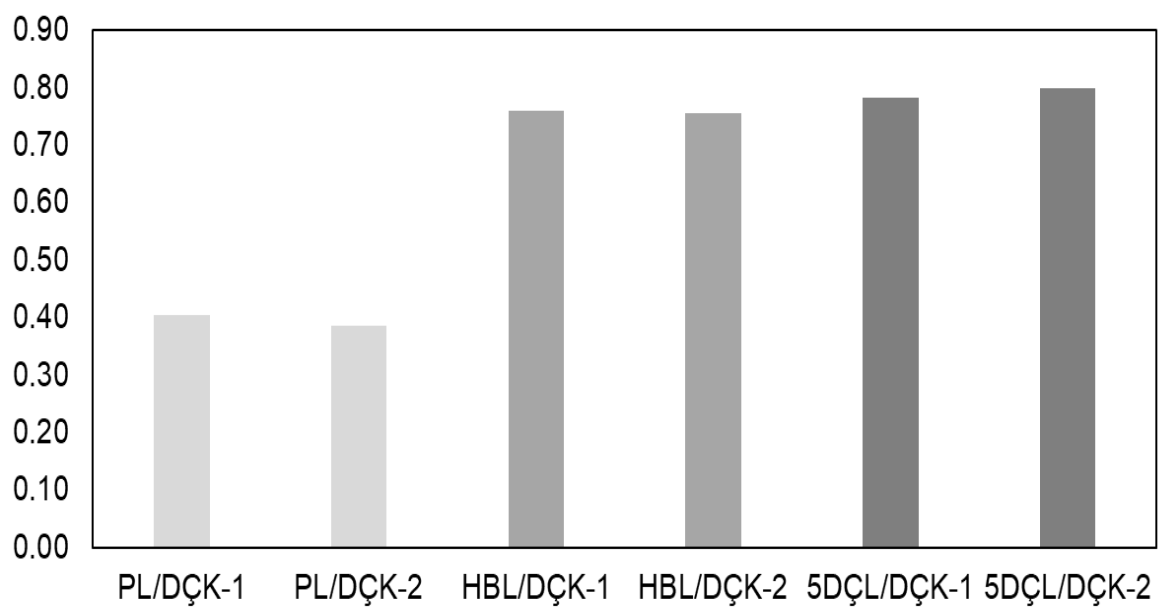

Şekil 6. Tekil ve hibrit lif donatılı çimento esaslı kompozitlerin pekleşme performansları 

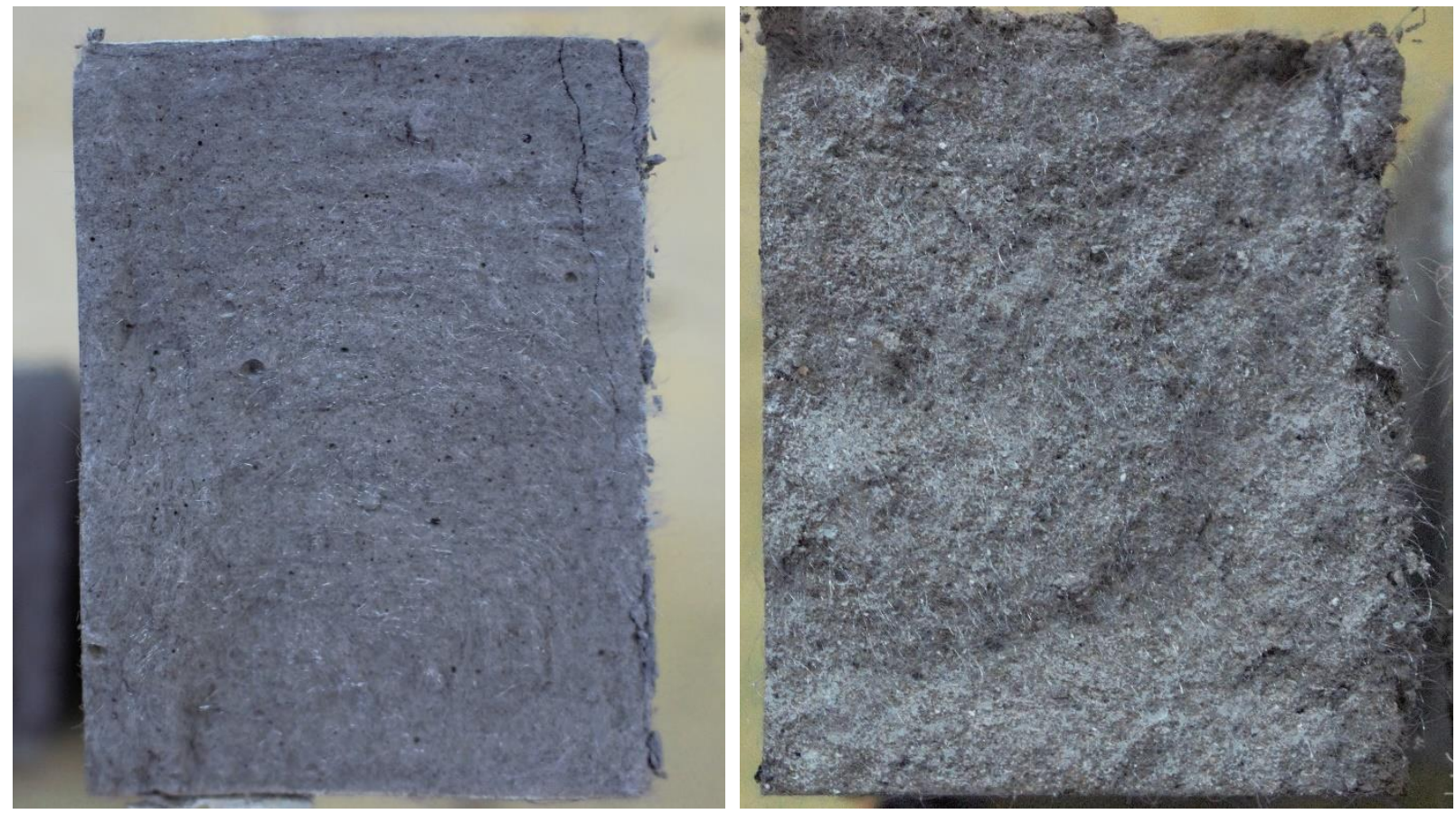

a) $\mathrm{PL} / \mathrm{DÇK}$

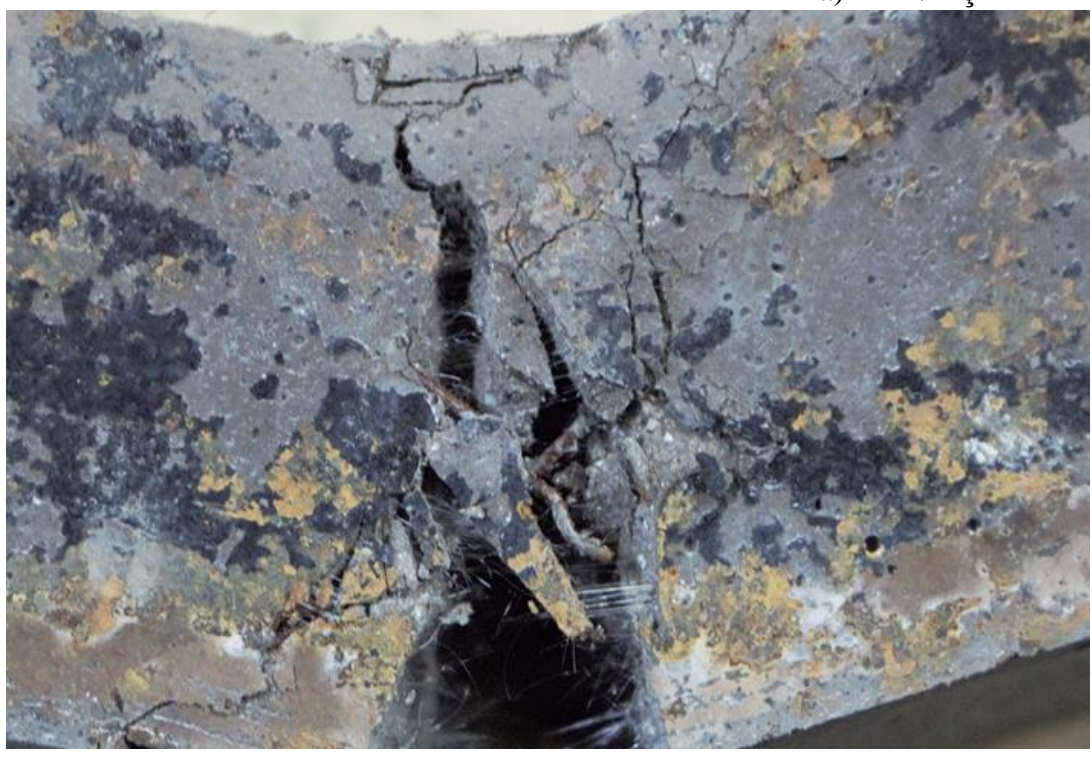

b) HBL/DÇK

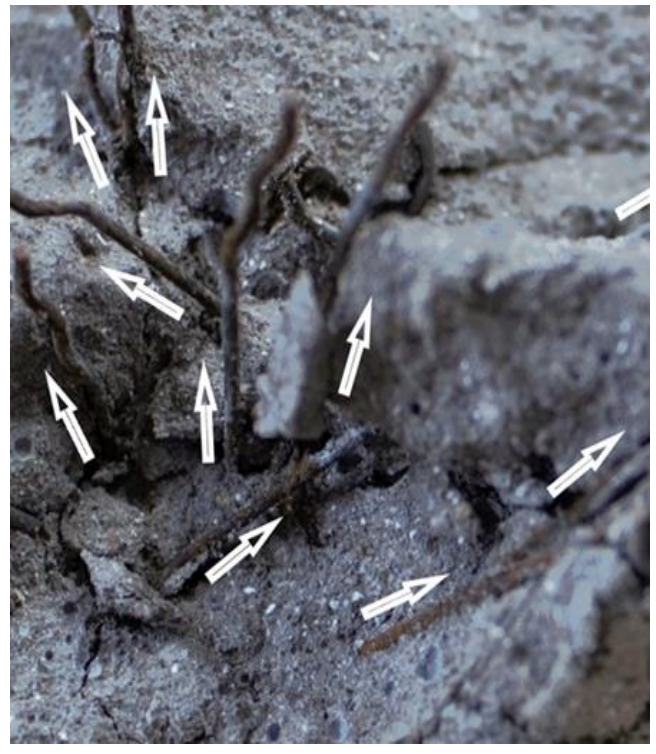

c) 5DÇL/DÇK

Şekil 7. Yüksek hacimde uçucu kül varlığında (\%80) üretilen tekil ve hibrit formdaki kiriş numunelerin deney sonrası gözle muayeneleri

\section{Sonuçlar}

$\mathrm{Bu}$ çalışmada, çimento esaslı kompozitlerde yüksek hacimde kullanılan uçucu küllerin varlığında tekil ve hibrit formda lifler kullanılmıştır. Geliştirilen çimento esaslı kompozit karışımları polyamid lif (PL) ve beş boyutlu çelik liflerle (5D-ÇL) donatılandırılmış ve mühendislik özellikleri irdelenmiş̧tir. Bunun yanında, farklı tür ve oranda lif donatılı kompozitlerin mekanik özellikleri 7, 28, 60 ve 90 günlük kür yaşlarında belirlenmiştir. Mühendislik özellikleri, ilk çatlak gerilmesi ve kırılma noktalarındaki yük ve deplasman değerleri, maksimum taşıma kapasitesi, süneklik oranı, rijitlik ve enerji yutma kapasitesi parametreleri üzerinden değerlendirilmiştir. Elde edilen bulgulardan aşağıdaki sonuçlara varılmıştır: 
- Toplam bağlayıcı ağılı̆ğınca \%80 oranında uçucu kül ile ikame edilen farklı lif donatılı çimento harç karışımlarının basınç mukavemetleri değerlendirilmiştir. Elde edilen sonuçlarda, her bir karışıma ait altı farklı numunenin ortalama basınç mukavemetlerine göre bütün karışımlar erken yaşta (7.gün) düşük basınç mukavemeti sergilemiştir (10,0-12,1 MPa). 28 günlük kür yaşlarında ise gerekli basınç mukavemetini (>30 MPa) gösterememiştir (18,1-22,2 MPa). Ancak 60 günlük (30,7-35,1 MPa) ve 90 günlük (33,9-38,9 MPa) kür yaşlarında bütün lif donatılı karışımlar yeterli basınç mukavemeti değerlerine sahiptir. Her ne kadar araştırma kapsamında olmasa da, daha ileri kür yaşlarında (>90 gün) karışımlar yoğun uçucu kül ihtiva ettiğinden yapılacak testler sonucu basınç dayanımlarında artışın devam etmesi beklenebilir.

- Basınç mukavemet değerleri karışımlar özelinde değerlendirildiğinde, erken yaştan (7.gün) başlamak üzere 90. Güne kadar bütün kür yaşlarında en yüksek basınç dayanımı sırasıyla PL/DÇK, HBL/DÇK, 5DÇL/DÇK karışımlarında elde edilmiştir. Bu noktada kür yaşından bağımsız olmak üzere, makro liflerin (5D-ÇL) mikro liflere göre (PL) basınç dayanımını kötüleştirdiği tespit edilmiştir.

- Sonuçlar bir arada kullanılan PL $(\% 0,5)$ ve 5D-ÇL $(\% 0,5)$ liflerinin tek formda $(\% 1)$ kullanılmalarına göre, matris ile lif arasındaki bağ davranışına kıyasla sinerji meydana getirdiğini ve buna bağlı olarak süneklik performansını ve enerji yutma kapasitesini önemli ölçüde arttırdığını işaret etmektedir. Bunun yanında tekil olarak kullanılan 5D-ÇL'lerin PL liflerine göre başlangıç rijitlik ve enerji yutma kapasitesi gibi davranışlarda daha olumlu olduğu düşünülürken, PL lifleri ise süneklik sağlama da 5D-ÇL'ye göre daha fazla avantaj sunmaktadır.

- Araştırma sonuçları, uçucu kül/çimento oranı ağırlıkça 4,0 olan çimento esaslı lif donatılı kompozitlerin, erken yaş mekanik özelliklerin belirleyici olmadığı ve daha hassas kür imkanlarının mümkün olduğu inşaat mühendisliği altyapılarında ekonomik, kalıcı ve yapısal performans açısından uygun bir tasarım olarak kullanılabileceğini göstermektedir.

\section{Referanslar}

Al-Kamyani, Z., Figueiredo, Fabio P., Hu, H., Guadagnini, M. \& Pilakoutas K. (2018). Shrinkage and flexural behaviour of free and restrained hybrid steel fibre reinforced concrete, Construction and Building Materials. 189(20), 1007-1018.

Balaguru, P.N \& Shah S.P. (1992). Fiber Reinforced Cement Composites. McGraw-Hill Inc. 37-84.

Betterman, L.R., Ouyang, C. \& Shah, S.P., (1995). Fiber-matrix interaction in microfiber-reinforced mortar, Advanced Cement-Based Materials (2), 53-61.

Demirel, Ö. \& Demirhan, S. (2021). Mikronize kalsit içeren yüksek hacimde uçucu kül katkılı çimento harçlarının mikroyapısal özelliklerinin incelenmesi, Journal of the Faculty of Engineering and Architecture of Gazi University, 36(4), 2250-2269.

Dehghani, A. \& Aslani, F. (2020). The effect of shape memory alloy, steel, and carbon fibres on fresh, mechanical, and electrical properties of self-compacting cementitious composites, Cement and Concrete Composites (112), 103659.

Doo-Yeol \& Yoo Banthia N. Impact resistance of fiber-reinforced concrete - A review (2019). Cement and Concrete Composites (104), 103389.

Hannesson, G., Kuder, K., Shogren, R. \& Lehman, D. (2021). The influence of high volume of fly ash and slag on the compressive strength of self-consolidating concrete. Construction and Building Materials. (30), 161-168.

Johnston, C.D. (2001). Fiber-reinforced cement and composites. Gordon and Breach Science Publishers, 24-49.

Kumbhar, D., Ganbavale, M., Jain, A., Reddy R \& Gayathri, S. (2014). Compressive Strength of Hybrid fibre reinforced concrete. Birla Institute of Technology and Science, Pilani, India.

Lawler J.S., Wilhelm T., Zampini D \& Shah SP. (2003). Fracture process of hybrid fiber reinforced mortar. Materials and Structures (36); 197-208.

Lawrence, P. Cyr, M. \& Ringot, E. (2003). Mineral admixtures in mortars - effect of inert materials on short-term hydration, Cement and Concrete Research. (33), 1939-1947.

Li Ye, Tan, K.H \& Yang, H. (2019). Synergistic effects of hybrid polypropylene and steel fibers on explosive spalling prevention of ultra-high performance concrete at elevated temperature. Cement and Concrete Composites. (96), 174-181.

Li, V. (2003). On Engineered Cementitious Composites (ECC) A Review of the Material and Its Applications. Journal of Advanced Concrete Technology. 1(3), 215-230.

Liu, J., Chen, H., Guan, B., Liu, K., Wen, J. \& Sun, Z. (2018). Influence of mineral nano-fibers on the physical properties of road cement concrete material, Construction and Building Materials. 190 (30), 287-293. 
Liu, J., Tan, K. H., Fan, S. (2018). Residual mechanical properties and spalling resistance of strain-hardening cementitious composite with Class C fly ash, Construction and Building Materials. (181), 30, 253-265.

Mehta, P.K. \& Monteiro, P.J.M. (2005) Concrete: Microstructure, Properties, and Materials, McGraw-Hill Education, 659.

Mobasber, B., Stang, H. \& Shah, S.P. (1990). Microcracking in fiber reinforced concrete, Cement and Concrete Research, (20), 66576.

Moon, G.D., Oh, S. \& Choi, Y.C. (2016). Effects of the physicochemical properties of fly ash on the compressive strength of highvolume fly ash mortar. Construction and Building Materials. (124), 1072-1080.

Nawy, E.G. (2001). Fundamentals of high-performance concrete. 2nd ed. John Wiley \& Sons, Inc. 246-289.

Öztürk, O \& Roig-Flores, M. (2021a). Effect of binary-use mineral admixtures for the advanced autogenous self-healing behavior of fiber-reinforced cementitious composites. International RILEM Conference on Early-age and Long-term Cracking in RC Structures, 389-401. Springer.

Öztürk, O \& Stefanidou M. (2021b). Sorptivity and mechanical properties of micro-fibrillated cellulose reinforced cementitious composites. Conference: International Conference on Cement-based Materials Tailored for a Sustainable Future, In the honour of Prof. Surendra P. Shah and Prof. Turan Özturan, İstanbul.

Öztürk O. Yenidünya E \& Keskin, Ü.S (2021). Effect of curing regimes on the mechanical and fresh properties of steel fiber-reinforced concrete, Architecture, Civil Engineering, Environment (4), 69-81.

Rahhal, V. \& Talero, R. (2005). Early hydration of Portland cement with crystalline mineral additions. Cement and Concrete Research. (35);1285-1291.

Sahmaran M., Yaman I.O. (2007). Hybrid fiber reinforced self-compacting concrete with a high-volume coarse fly ash. Construction and Building Materials. (21), 150-156.

Sanchez, D., \& King-Toler, E. (2007). Addressing disparities consultation and outreach strategies for university settings. Consulting Psychology Journal: Practice and Research, 59(4), 286-295. doi:10.1037/1065- 9293.59.4.286

Sunayana, S. \& Barai, S.V. (2017). Recycled aggregate concrete incorporating fly ash: Comparative study on particle packing and conventional method, Construction and Building Materials, 156 (15), 376-386.

TBDY (2019). Türkiye Bina Deprem Yönetmeliği. Deprem Etkisi Altında Binaların Tasarımı İçin Esaslar. Ankara: 1-416.

Van Vugt, M., Hogan, R., v Kaiser, R. B. (2008). Leadership, followership, and evolution: Some lessons from the past. American Psychologist, 63(3), 182-196. doi:10.1037/0003-066X.63.3.182

Wang, S. \& Li V.C. (2007) Engineered Cementitious Composites with High-Volume Fly Ash, Materials Journal. 104(3) 233-241.

Wei, J., Li, J. Wu, C., Liu, Z. \& Li, J. (2021). Hybrid fibre reinforced ultra-high performance concrete beams under static and impact loads, Engineering Structures. 245(15), 112921.

Zhang, D., Yu Tan, G. \& Tan, K.H. (2021). Combined effect of flax fibers and steel fibers on spalling resistance of ultra-high performance concrete at high temperature. Cement and Concrete Composites. (121), 104067.

Zheng, Y., Wu, X., He, G., Shang, Q., Xu, J. \& Sun, Y. (2018). Mechanical properties of steel fiber-reinforced concrete by vibratory mixing Technology. Advances in Civil Engineering. 025715, 1-11 